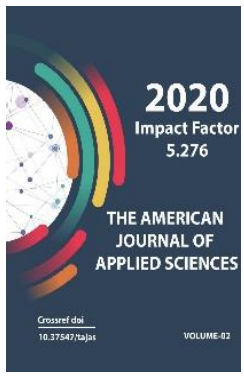

Journal Website: http://usajournalshub.c om/index,php/tajas

Copyright: Original content from this work may be used under the terms of the creative commons attributes 4.0 licence.

\section{Study Of Virulent Characteristics Of Wheat Yellow Rust (Puccina Striiformis F.Sp. Tritica) In Uzbekistan}

\author{
Dilshod Akhmatovich Mullaev \\ Phd Student, Institute Of Genetics And Experimental Biology Of Plants,
} Academy Of Sciences Of The Republic Of Uzbekistan

Khurshid Sadullaevich Torakulov

Candidate Of Biological Sciences, Senior Researcher, Institute Of Genetics And Experimental Biology Of Plants, Academy Of Sciences Of The Republic Of Uzbekistan

Bakhodir Khorozovich Chinikulov

Candidate Of Biological Sciences, Senior Researcher, Institute Of Genetics And Experimental Biology Of Plants, Academy Of Sciences Of The Republic Of Uzbekistan

Doston Sheralievich Erjigitov

Practitioner Researcher, Institute Of Genetics And Experimental Biology Of Plants, Academy Of Sciences Of The Republic Of Uzbekistan

Isokulov Siroj Murtoza Ogli

Junior Researcher, Institute Of Genetics And Experimental Biology Of Plants, Academy Of Sciences Of The Republic Of Uzbekistan

\title{
ABSTRACT
}

The article examines the virulence of the isolation of wheat yellow rust (Puccina striiformis f.sp. tritica), one of the main problems of the grain industry, from Bekabad district of Tashkent region of the Republic of Uzbekistan. The racial formula of the disease sample was found to be $239 \mathrm{E} 242$ in terms of virulence, and the virulence of this race relative to genes using isogenic lines known to contain genes responsible for yellow rust disease.

\section{KEYWORDS}

Wheat, race, yellow rust, inoculation, gene, disease, virulent, avirulent.

\section{INTRODUCTION}

In many countries around the world, including Uzbekistan, rust fungi are the most dangerous diseases of wheat. Two of them, yellow and brown rust, are common in the wheat fields of our country, and in some years they are widespread, leading to the loss of many crops [1, pp. 9-10]. 
In the climatic conditions of the country, the damage of yellow rust to wheat is more dangerous than brown rust [2, pp. 29-30].

Yellow rust disease Puccinia striiformis Westend. (Ps) is one of the most harmful diseases found in cereal crops caused by fungi [3, pp. 129-141].

The causative agent of yellow rust disease grows well at low temperatures and occurs frequently in temperate areas. Epidemics of mainly yellow rust disease develop rapidly and spread very rapidly in areas with warm and sufficient humidity [4, pp. 20.1-20.21; 5, pp. 299-307]. Puccinia striformis f.sp. tritici is a fungus with the largest variability in virulence (the ability of a pathogen to infect a plant) [6, pp. 89-124]. Yellow rust disease of winter soft wheat has been studied in our country by a number of scientists. In particular, large-scale research in our country has been conducted since the 1970 s by scientists of the Central Asian Research Institute of Phytopathology [7, p. 367], [8, p. 48], [9, p. 90], [10, p. 125], [11, 94]. In 1965-1974, the Central Asian Scientific Research Institute of Phytopathology monitored the composition of yellow rust species in Central Asia and southern Kazakhstan. Each year, the isolation of the fungus from 27-30 to 116-148 is analyzed in the international set of differentiating varieties Gassner and Straif. 17 physiological races of Puccinia striiformis f.sp.tritici have been identified, including: 20, 23. 25. 31, 40, 42, 5/6, A1, A 2, A 3, A 4, A 7, A 8, A 9, A $10 \mathrm{~S}$ and so on [10, p. 125], [11, -. 94].

\section{THE MAIN PART}

The widest range of races was recorded in 1988. All pathogenic races found in wheat in the region have been studied. In wild grasses, only 5 breeds were identified: 6E20, 6E22, $6 \mathrm{E} 148,6 \mathrm{E} 150$ and $7 \mathrm{E}_{148}$. In the population of yellow rust fungus, 6E20, $7 \mathrm{E}_{20}$ and $7 \mathrm{E} 148$ races have been observed annually. The $6 \mathrm{E} 148$ race was recorded in 1987-1989 and accounted for the largest proportion (41.3-21.7\%) of these races. [[8, p. 48], [9, p. 90], [11, p. 94]. From 1994 to the present, a number of scientists in Uzbekistan S.Baboev, B.Khasanov, H.Turakulov, R.Gulmurodov, A.Amanov and others have developed effective chemical control measures against yellow rust in the grain industry of the republic, conducted research on resistant varieties and extensive scientific research has been conducted on the identification of genes resistant to local races. Samples with Yr5, Yr10, Yr15, Yr26 genes for yellow rust in our country showed absolute resistance to local races of yellow rust. Relative resistance is shown by the genes $\mathrm{Yr} 4$ ?, Yr17, Yr25, and it has been shown that these genes are still highly effective in selection projects. Moderate intolerance was expressed by Yr2, Yr29, Yr8, YrSP, Yr18, Yr32 genes [12, pp. 261-264].

Based on the above data, one of the urgent issues for the development of the grain industry in our country is to identify local breeds of yellow rust diseases (Puccinia striiformis f.sp.triticm) and to create varieties resistant to yellow rust races.

\section{MATERIALS AND METHODS}

Isolate was obtained from wheat fields in Bekabad district of Tashkent region of the Republic of Uzbekistan in late April, during the main season of yellow rust disease in wheat fields. In the field, a sample of urediniospores of yellow rust disease was collected by placing the infected plant leaves in air-permeable paper bags. The diseased leaves were air-dried and kept at an air temperature of $+4-+5 \mathrm{OC}$ until inoculation [13, p. 205]. 
Reproduction of urediniospores. Initially, the Moroccan variety was grown in pots in the laboratory. The Moroccan variety is recognized as an important hardy variety.

Diseased leaves, collected to revive the urediniospores of yellow rust fungi and stored at an air temperature of $+4-+5 \mathrm{OC}$, were removed and placed in Petri dishes placed in filter paper, moistened with water. Store in a dark environment for $10-15$ hours. The urediniospores derived from the urediniopustila on the leaf were then inoculated in the form of a monopustila from the Morocco navigator after the removal of the 2 leaves. For incubation, it was placed at
9-100C at 98-100\% humidity. After 24 hours, the plants were placed in a room at a temperature of $+16-+18$ oC for 12 hours a day (10,000 lux). Yellow rust urediniospores were collected after 18-20 days.

Yellow rust disease virulence analysis and disease race identification. The study of wheat yellow rust sample was carried out in the laboratory under the Johnson. $R$ et al method by determining the resistance of the set of differentiating varieties of genes responsible for specific yellow rust disease in the germination phase (Table 1). There are 17 of these varieties, of which 9 are worldwide and 8 are European varieties [14, pp. 475-480].

\section{Table 1}

International and European collection used in the detection of yellow rust disease race.

\begin{tabular}{|c|l|c|c|}
\hline \multicolumn{1}{|c|}{ International collection } & Genes & Decimal levels \\
\hline 1. & Chinese 166 & Yr1 & $1\left(=2^{\circ}\right)$ \\
\hline 2. & Lee & Yr7 & $2\left(=2^{1}\right)$ \\
\hline 3. & Heines Kolben & Yr6,Yr2 & $4\left(=2^{2}\right)$ \\
\hline 4. & Vilmorin & Yr3V & $8\left(=2^{3}\right)$ \\
\hline 5. & Moro & Yr10 & $16\left(=2^{4}\right)$ \\
\hline 6. & Strubes Dickkopf & YrSd & $32\left(=2^{5}\right)$ \\
\hline 7. & Suwon92 x Omar & YrSu & $64\left(=2^{6}\right)$ \\
\hline 8. & Clement & Yrg, Yr2+,Cle & $128\left(=2^{7}\right)$ \\
\hline 9. & Triticum spelta & Yr5 & $256\left(=2^{8}\right)$ \\
\hline & European collection & & $1\left(=2^{0}\right)$ \\
\hline 10. & Hybrid 46 & Yr4+ & \\
\hline
\end{tabular}




\begin{tabular}{|c|l|c|c|} 
11. & Reichersberg42 & Yr7+ & $2\left(=2^{1}\right)$ \\
\hline 12. & Heines Peko & Yr6,Yr2+ & $4\left(=2^{2}\right)$ \\
\hline 13. & Nord Deprez & Yr3N & $8\left(=2^{3}\right)$ \\
\hline 14. & Compair & Yr8,YrAPR & $16\left(=2^{4}\right)$ \\
\hline 15. & Carstens V & Yr32,YrCV & $32\left(=2^{5}\right)$ \\
\hline 16. & Spaldings prolific & YrSp & $64\left(=2^{6}\right)$ \\
\hline 17. & Heines VII & Yr2+ & $128\left(=2^{7}\right)$ \\
\hline
\end{tabular}

and first-leaf fully opened wheat grasses

Additional $(\mathrm{Yr}$ 1/6*Avocet $\mathrm{S}, \mathrm{Yr} 1 / 6 * A v \mathrm{~S}$, Chinese 166(W;Yr1), Kalyansona (S), Yr5/6*Avocet $S, \operatorname{Yr} 6 / 6 * A$ vocet $S$, Fielder, $\mathrm{Yr}$ 7/6*Avaset $S$, Thatcher, $\operatorname{Yr} 9 / 6 *$ Avocet $S$, Fed 4/Kavkaz (Yrg), Yr 10/6* Avocet S, Yr 15/ 6" Avocet S, Yr32/6*Avocet S, Yr SP / 6* Avocet S, Avocet 'R', Inia 66, Yr 18/ 3' Avocet S, Jupateco 'R' (S), Anza, Cook (S), YR27/6'Avocet S, Ciano 79, ATTILA CM8583650Y, OPATA 85, Avocet-YRA*3/3/ALTAR 84/AE. SQ//OPATA, AVOCET - YRA'3/PASTOR Yr31, Yr8 Avocet NIL, Yr17 Avocet NIL, Lal Bahodur (Yr29), Pastor (Yr31+APR), Yr7 Avocet NIL, Fed4/Kavkaz (Yr9), TPI 1295 (Yr25), Yr27 Avocet NIL) lines and Morocco as a resistant control variety were used to further study the virulence properties of the isolate.

Wheat seeds were sown in 7-8 pieces in pots with a diameter of $10 \mathrm{~cm}$ in a mixture of soil, sand and humus (3:3: 4 ratios).

Urediniospores propagated in the Moroccan variety were inoculated by spraying 10 -day-old mixed with Soltrol 170 mineral oil. Inoculated samples were left for 24 hours in a dark environment at an air temperature of $+9-+10$ $O C$ and $100 \%$ humidity to carry out the incubation process. The samples were then grown in $a+16-+18$ oC greenhouse for 12 hours a day, under 10,000 fluorescent lamps.

Evaluation of samples. Assessment of yellow rust resistance in grasses was assessed after 14-17 days on the basis of 0-9 points, with 0-6 points determining avirulence and 7-9 points' virulence [14, pp. 475-480].

\section{RESULTS AND DISCUSSION}

In our experiment, a sample of yellow rust (Puccina striiformis f.sp. tritica) from Bekabad district of Tashkent region was studied. International and European kits for yellow rust disease isolation were evaluated based on the response of differentiator varieties (Table 2 ).

International and European sets were evaluated based on the response of differentiator varieties (Table 2). 


\section{Table 2}

Virulence of yellow rust pathogens collected from Tashkent region in relation to differentiating varieties

\begin{tabular}{|c|c|c|c|c|}
\hline \multicolumn{2}{|c|}{ Differentiator varieties } & \multirow{3}{*}{$\begin{array}{l}\text { Genes } \\
\begin{aligned} \\
\text { Yr1 }\end{aligned}\end{array}$} & \multicolumn{2}{|c|}{ Morbidity rate (points) } \\
\hline & & & 1 return & 2 return \\
\hline 1 & Chinese 166 & & 7 & 8 \\
\hline 2 & Lee & Yr7 & 7 & 7 \\
\hline 3 & Heines Kolben & Yr6,Yr2 & 7 & 8 \\
\hline 4 & Vilmorin & Yr3V & 8 & 7 \\
\hline 5 & Moro & Yr10 & 0 & 0 \\
\hline 6 & Strubes Dickkopf & YrSd & 7 & 7 \\
\hline 7 & Suwong2 x Omar & YrSu & 8 & 8 \\
\hline 8 & Clement & Yrg,Yr2+,Cle & 7 & 8 \\
\hline 9 & Triticum spelta & Yr5 & 0 & 0 \\
\hline 10 & Hybrid 46 & Yr4+ & 4 & 4 \\
\hline 11 & Reichersberg42 & Yr7+ & 7 & 7 \\
\hline 12 & Heines Peko & Yr6,Yr2+ & 6 & 5 \\
\hline 13 & Nord Deprez & Yr3N & 6 & 6 \\
\hline 14 & Compair & Yr8,YrAPR & 7 & 8 \\
\hline 15 & Carstens V & Yr32,YrCv & 8 & 8 \\
\hline 16 & Spaldings prolific & YrSp & 8 & 9 \\
\hline 17 & Heines VII & Yr2+ & 8 & 9 \\
\hline
\end{tabular}


According to the evaluation results, the yellow rust disease sample was able to infect Chinese 166, Lee, Heines Kolben, Vilmorin, Strubes Dickkopf, Suwong2 x Omar and Clement varieties from the International Collection. In Moro and Triticum spelta, no symptoms of the disease were observed with respect to isolation. The local race from the European collection showed virulence in Reichersberg 42, Compair, Carstens V, Spalding Prolific and Heines VII, and avirulence in Hybrid 46, Heines Peco and Nord Desprez.
By adding the values of the degree of yellow rust isolation in differentiated varieties of virulence observed in Table 1, it was determined that the racial formula of the sample of yellow rust (Puccina striiformis f.sp. tritica) from Bekabad district of Tashkent region was 239E242.

For a more extensive study of the $239 \mathrm{E} 242$ race of yellow rust disease, the virulence of the genes in response to yellow rust disease in the genotype was examined relative to the genes using known isogenic lines (Table 3 ).

\section{Table 3}

Levels of resistance to disease $239 \mathrm{E} 242$ race of genes in the genotype of known genes responsible for yellow rust disease

\begin{tabular}{|c|c|c|c|c|}
\hline \multirow[t]{2}{*}{ № } & \multirow[t]{2}{*}{ Lines } & \multirow[t]{2}{*}{ Genes } & \multicolumn{2}{|c|}{ Morbidity rate (points) } \\
\hline & & & 1 return & 2 return \\
\hline 1 & $\operatorname{Yr} 1 / 6 *$ Avocet $S$ & Yr 1 & 8 & 7 \\
\hline 2 & $\operatorname{Yr} 1 / 6 * A v S$ & NIL 1 & 8 & 8 \\
\hline 3 & Chinese 166(W;Yr1) & $(\mathrm{W} ; \mathrm{Yr} 1)$ & 8 & 7 \\
\hline 4 & Kalyansona (S) & $\operatorname{Yr} 2$ & 7 & 8 \\
\hline 5 & $\operatorname{Yr} 5 / 6 *$ Avocet S & Yr 5 & 0 & 0 \\
\hline 6 & Yr 6/6*Avocet S & Yr 6 & 7 & 8 \\
\hline 7 & Fielder & $\operatorname{Yr} 6, \operatorname{Yr} 20$ & 8 & 8 \\
\hline 8 & Yr $7 / 6 *$ Avaset S & Yr 7 & 7 & 7 \\
\hline 9 & Thatcher & Yr 7 & 8 & 7 \\
\hline
\end{tabular}




\begin{tabular}{|c|c|c|c|c|}
\hline 10 & Yr 9/6* Avocet S & Yr 9 & 8 & 8 \\
\hline 11 & Fed 4/Kavkaz (Yrg) & Yr 9 & 9 & 8 \\
\hline 12 & $\operatorname{Yr} 10 / 6 *$ Avocet $S$ & Yr 10 & 0 & 1 \\
\hline 13 & Yr 15/ 6'Avocet S & Yr 15 & 0 & 0 \\
\hline 14 & Yr32/6*Avocet S & $\operatorname{Yr} 32$ & 7 & 8 \\
\hline 15 & Yr SP / 6* Avocet S & Yr SP & 8 & 8 \\
\hline 16 & Avocet 'R' & YrA & 8 & 8 \\
\hline 17 & Inia 66 & YrA & 7 & 8 \\
\hline 18 & Yr 18/ 3' Avocet S & $\operatorname{Yr} 18$ & 7 & 8 \\
\hline 19 & Jupateco 'R' (S) & Yr 18+ & 7 & 7 \\
\hline 20 & Anza & Yr A, Yr 18 & 5 & 6 \\
\hline 21 & $\operatorname{Cook}(\mathrm{S})$ & APR & 9 & 8 \\
\hline 22 & Lemhi & Yr 21 & 8 & 8 \\
\hline 23 & TP1295 & Yr 25 & 6 & 5 \\
\hline 24 & YR27/6'Avocet S & Yr 27 & 7 & 8 \\
\hline 25 & Ciano 79 & Yr 27 & 7 & 7 \\
\hline 26 & ATTILA CM85836-50Y & Yr 27+? & 7 & 8 \\
\hline 27 & OPATA 85 & $\operatorname{Yr} 27+\operatorname{Yr} 18$ & 7 & 7 \\
\hline 28 & $\begin{array}{l}\text { Avocet-YRA*3/3/ALTAR } \\
\text { 84/AE. SQ//OPATA }\end{array}$ & Yr 28 & 6 & 6 \\
\hline 29 & $\begin{array}{l}\text { AVOCET - YRA'3/PASTOR } \\
\text { Yr31 }\end{array}$ & Yr 31 & 5 & 6 \\
\hline 30 & Yr8 Avocet NIL & Yr8 & 8 & 8 \\
\hline 31 & Yr17 Avocet NIL & Yr17 & 7 & 8 \\
\hline
\end{tabular}




\begin{tabular}{|c|l|l|c|c|}
\hline 32 & Lal Bahodur (Yr29) & Yr29 & 6 & 6 \\
\hline 33 & Pastor (Yr31+APR) & Yr31+APR & 7 & 8 \\
\hline 34 & Yr7 Avocet NIL & Yr7 & 8 & 7 \\
\hline 35 & Fed4/Kavkaz (Yr9) & Yr9 & 9 & 9 \\
\hline 36 & Yr27 Avocet NIL & Yr27 & 8 & 9 \\
\hline 37 & Morocco & & 9 & 9 \\
\hline
\end{tabular}

Based on the evaluation results, $239 \mathrm{E} 242$ showed virulence relative to most plant lines. This race showed avirulence to only $\mathrm{Yr}$ 5/6*Avocet S, Yr 10/6* Avocet S, Yr 15/ 6" Avocet S, Anza, TP1295, AvocetYRA*3/3/ALTAR84/AE.SQ//OPATA, AVOCETYRA'3/PASTOR Yr31 and Lal Bahodur (Yr29) lines.

Summarizing the results of the evaluation of isogenic lines, international and European collections, the local $239 \mathrm{E} 242$ race of yellow rust disease in the monogenic state of the genes Yr10, Yr5, Yr3N, Yr 15, Yr 25, Yr29, Yr 31, Yr 28 and in the combination of Yr6, Yr2 + and YrA, Yr18 genes showed avirulence. It should be noted that the $\mathrm{YrA}$ and $\mathrm{Yr} 18$ genes in the monogenic state showed virulence to each of the local race genes. In one genotype, $239 E 242$ showed race avirulence when the YrA, Yr18 gene came in combination. This suggests that yellow rust disease may be caused by the combination of two or more genes in a single plant with genes that have shown virulence in the race, causing the race to show avirulence in that plant. The results also show that the local race virulence spectrum was observed to be higher than that of the races studied in previous years.

\section{CONCLUSION}

In Tashkent region, the presence of yellow rust (Puccina striiformis f.sp. tritica) 239E242 was detected. It has been observed that the genes responsible for yellow rust disease, which exhibit virulence in the monogenic state of yellow rust disease races, are in the same genotype in a combination of two or more, causing the races to show avirulence relative to the plant. The $239 \mathrm{E} 242$ local race studied in the region was noted to have a high virulence spectrum. The results of the study show that the search for new sources of disease resistance and the study of the reactions of genes responsible for yellow rust to yellow rust in various combinations show that it is necessary for the future of the grain industry of the Republic.

\section{REFERENCES}

1. Khasanov B.A., Ochilov R.O. (2010) Recommendations for the detection, registration and control of wheat rust. Tashkent. - pp. 9-10. 
2. Siddiqov.R, Umirov.N, Yusupov. N, Mamatqulov.l. (2018) New varieties and ridges of soft wheat resistant to yellow rust, high grain yield for irrigated areas // J. Agro science. № 5 (55). - pp. 29-30.

3. Wellings. C. R. (2011y) Global status of stripe rust a review of historical and current threats // Euphytica: - 179. - pp. 129-141.

4. Hovmoller, M. S., Sorensen, C. K., Walter. S and Justesen. A. F. (2011) Diversity of Pucciniia striiformis on cereals and grasses //Annu. Rev. Phytopathol. - pp. 20.1-20.21.

5. Mboup. M., Leconte. M., Gautier. A., Wan. A.M., Chen. W.Q., de Vallavieille-Pope. C. and Enjalbert. J. (2009) Evidence of genetic recombination in wheat yellow rust population of a Chinese oversummering area // Fungal Genet. Boil. pp. 299-307.

6. Kolmer J., Chen X., Jin Y. (2009) Diseases which challenge global wheat productionThe wheat rusts //Wheat, Science and trade. B.E. Carver, ed. Wiley-Blackwell, Ames, I.A. - pp. 89-124.

7. Koyishboyev M. (2002) Diseases of grain crops. - Alma-ata: Bastau. - p. 367.

8. Kratenko V.P., Solotchina G.F., Bazhenova V.M. (1987) "Pruning-3.1" Study of intrapopulation processes in wheat rust pathogens in order to predict the state of the virulence gene pool // Report for 1987 (annual). - Tashkent. - p. 48.

9. Solotchina G.F., Bazhenova V.M., Yakubova E.V. (1990) Topic: "Pruning-3.1" Study of intrapopulation processes in wheat rust pathogens in order to predict the state of the virulence gene pool // Report on research for 1986-1990. (final). - Tashkent - p. 90.

10. Chkanikov D.I., Konovalova N.E., Suzdalskaya M.V., Smirnova L.A., Kulikova
G.N. (1980) Study of the dynamics of the racial composition of causative agents of rust diseases of grain crops in the USSR // Final report for 1976-1980. -Theme No. 9.2-179-76 PC. - Tashkent. - p. 125.

11. Shavarina Z.G. (1990) Study of intrapopulation processes in wheat rust pathogens in order to predict the state of the virulence gene pool. Research reports of the Central Asian Research Institute of Phytopathology for 1977-1989. Tashkent. - p. 94.

12. Turakulov H., Khasanov B., Gulmurodov R.A., Alimardonov Sh. R. (2014) Identification of wheat rust resistance genes in Uzbekistan // Current state and prospects of selection and seed production. Republican scientific-practical conference. -Tashkent. - pp. 261-264.

13. Melntosh, R.A., Wellings, C.R., and Park, R.F. (1995) Wheat rusts: an atlas of resistantce genes // Commonwealth Scientific and Industrial Research Organization, Australia, and Kluwer Academic Publishers, Dordrecht, Netherlands. - p. 205.

14. Jonnson.R., Sttubbs.W., Fuchs.E. and Chamberian.N.H. 1972. Nomenclature for physiologic races of Puccinia striuformif infecting wheat// Trans.Br.Mycol. Soc. pp. 475-480. 